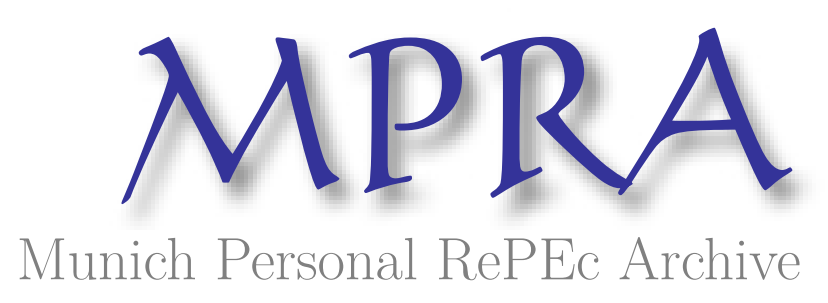

\title{
The economic value of the Earth's resources
}

Chichilnisky, Graciela

1995

Online at https://mpra.ub.uni-muenchen.de/8491/

MPRA Paper No. 8491, posted 28 Apr 2008 02:55 UTC 
environment. II. The influence of travel costs and structure of the environment, $J$. Anim Ecol. 60, 205-225

27 Smith, A.T. and Peacock, M.M. (1990) Conspecific attraction and the determination of metapopulation colonization rates, Consere. Bicl. 4 $320-323$

28 Robiuson, S.K. ef ul. (1995) Regional forest fragmentation and the nesting success of migratory birds, Science 267 , $198 \bar{i}-1990$
29 Hanski, I, and 7.hang, D-Y. (1993) Migration, metapopulation dynamics and fugitive co-existence, J. Theor. Biol 163, 491-504

30) Dunning. J.R., Jr, Daniclson, R.J, and Pulliam, H.R (1992) Ecological processes that affect populations in complex landscapes, Uikos $65,169-175$

31 Reed, J.M, and Dotuson, A.P. (1993) Behavioural constraints and conservation biology: conspecinic attraction and recruitment, Trends Ecol. EvoL 8 , $253-256$
32 Wiens, J,A. ef ol (1995) Fractal patterns of insect movement in microlandscape mosaics. Ecology 76, 663-660

33 Yeomans, 5.R. (1995) Water-finding in adult turtles: random search or oriented behaviour? Arrim. Beha: 49,977-987

34 Nottingham, S.F. (1988) Host-plant finding for oviposition by adult cabbage root $\mathrm{ny}$, Delia radicum, J. Insect Physiol. 34, 227-234

35 Ray, C., Gilpin, M. and Smith, A.T. (1991) The effect of conspecific attraction on metapopulation dynamiex, Binl I. Linn .Sx. 42, 12.1-134

\section{The economic value of the Earth's}

\section{resources}

\section{Graciela Chichilnisky}

Economics is the driving force of today's widespread environmental destruction. Markets undervalue the earth's resources and compound their overuse. Since World War II the world has used resources voraciously. The situation can be described as the industrial countries overconsuming resources, which are overextracted and exported by developing countries and traded at prices that are lower than the social costs. Resource-intensive patterns of growth and trade are inefficient for the world economy, and lead to tragic maldistribution of the Earth's riches. They should be replaced by knowledge-intensive patterns of growth. Information technology and the environmental agenda are two of the most important trends in the world economy.

Together they can lead to growth that is intrinsically compatible with the environment.

Graciela Chichilnisky is at the Program

on Information and Resources, Columbia University, 405 Low Library, 116 th and Broadway. New York, NY 10027, USA (gc90columbiatedu).

$\mathrm{W}$ hat is the economic value of the Earth's resources? The question is classical and has more than one answer. Market economies value goods and services by their market prices. These are the prices that clear markets, equating supply with demand. They simultaneously reflect costs of production and consumer preferences.

Under ideal circumstances market prices lead to efficient patterns of resource allocation, which cannot be improved so as to make everyone better off. These are valuable properties, buttressed by theory and by some economic evidence. Yet there is increasing unease today about the pricing of resources. Physical scientists question economic wisdom, and the matter has become the subject of popular debatel.

Part of the problem is the lack of organized markets. The problem is acute in the case of water and air. There are no organized markets, and therefore no market prices, for either. In some cases, users pay for water, but the price is divorced from competitive markets, and therefore from efficiency. In the case of air, a further dif- ficulty emerges: one individual cannot easily choose air quality independently from others. For such goods, called 'public goods', standard markets do not work well. Efficiency is lost. The problem of pricing resources is pervasive. In practice, many scarce and valuable resources have zero prices. For example the achievement of cleaner water and air have zero economic value in all systems of economic accounting used today.

Faulty prices compromise the evaluation of economic progress. For example, we burn fossil fuels to produce industrial output. This output has an economic value, but clean air does not. Therefore, burning fossil fuels has an unequivocally positive economic value, and counts as economic progress even as it pollutes the air and can cause climate change. A similar situation emerges with respect to the world's forests: the destruction of a forest in order to extract its wood or to grow agricultural products has an unequivocally positive value, and is counted as economic progress all over the world. In a world increasingly concerned with the survival of its for- ests and with its clean air and water, this vision of economic progress defies common sense. It is now under close scrutiny.

It has been pointed out that markets for environmental assets may never emerge, and that, even if they do, they may not act efficiently ${ }^{2-4}$. Wider notions of economic value are being proposed by some, including myself, in an attempt to reconcile equity and efficiency, as well as to balance the weight given to the present and the future ${ }^{2-5}$. This article cannot, and will not, cover all the issues, important as they are. It will discuss basic needs and environmental markets. As an organizing theme, I will propose that we must now focus on the choice between two, fundamentally different, patterns of growth: resourceintensive and knowledge-intensive. One works and the other doesn't. Economic progress is not doing more with more: it is doing more with less.

Before suggesting solutions, however, one should understand the nature of the problem: what is driving our unease? Why is the question of economic valuation of the Earth's resources now timely and somewhat controversial? What is the source of the problem? To answer these questions a brief review of the situation is required.

\section{The global environment today}

Human beings, or their close genetic relatives, have lived on Earth for several million years. Yet only recently has human activity reached levels at which it can aflect natural processes such as the concentration of gases $\left(\mathrm{CFC}, \mathrm{CO}_{2}\right)$ in the atmosphere of the planet, the stability of the global climate, and the complex web of species that constitutes life on earth. There is no consensus about the magnitude of these impacts, but it is widely agreed that, for the first time in recorded history, economic activity has reached levels at which it can alter the planet's atmosphere and endanger its biodiversity ${ }^{6-8}$

At the. June 1992 Earth Summit in Rin de Janeiro, 150 countries chose three areas in which concerted international action is urgently needed - Biodiversity, Climate Change, and Sustainable Development - 


\section{Box 1. The North-South contrast}

Most ol the damage to the global enwironment originates iand has originated historically in the industria countries that house ess than $30 \%$ of the world's population". It is the industria countries that are overcon suming environmental resources, which are largely overextracted and exported by the developing countries. About $70 \%$ of the worlds' carton dioxide and most CFCs are emizted by the industria lized countries in the North. These countries have also substantially altered their aiomass; most of the world's remaining bio viversity and forests are in the developing countries, mustly in the South. The Narth-South conlrast is strik. ing: the averase inhabitant of an industrinl country consumes nine tirres more fossil fuels, six times more beef and veal, 20 times more alumizium, 16 times more copper, two and a half times more wood and emits ten times more carbon than the correspond ng average person in e ceveloping country ${ }^{n}$. Replicating the North's pattem in the South, which contairs most of the worids' popul ation, predicates disaster

Since the North has the lowest population growth, desp te all publicity to the cortrary. global environ mental damage is, and always has been, inversely related to populat on growth. This trend could, of course, he roversed in the future, and rejons with rapid population growth could produce most enironmentai dam age 50 years from now. and created corresponding Framework Conventions'.

\section{Resource prices and overconsumption}

On the whole, the situation today can be described as the industrial countries (the North) overconsuming environmental resources, which are overextracted in the developing countries (the South). While the North houses less that one third of humankind, it consumes most of the world's exhaustible resources, such as fossil fuels: metals and minerals, and most of the renewable resuurces obtained from fertile land, such as wood, livestock and cotton. Contrary to common wisdom, the lesspopulated regions cause the most global environmental damage. Box 1 summarizes

Mineral fuels provide an extreme casc of delivery of a primary, nonrenewable resource from developing countries to industrialized countries. Nearly three fourths of Southern exports of mineral fuels are sent to the North, and $60 \%$ of the North's consumption of mineral fuels comes from the South ${ }^{s}$. Latin America exports mostly resources - indeed about $70 \%$ of its exports are resources - and Africa does so almost exclusively. The US alone, with less than $5 \%$ of the world's population, conit has followed a voracious trend which accelerated after World War II (Ref. 8).

The pricing of resources is a crucial aspect of the problem. The world's rapid rate of consumption of fossil fuels is linked to the low international prices of petroleum. The same problem arises in the overuse of forests as a source of wood and is the consumption. Overconsumption is practically synonymous with underpricing (see Box 2).

How has this situation evolved? Why tion and overconsumption of the world's resources, beyond the point of sustainability? Equivalently, why are the world's resources traded at such low prices? the overall situation. sumes an enormous quantity of materials: wood pulp. The lower the prices, the higher have we reached this pattern of overextrac-

\section{Prices, basic needs and the measurement of economic progress}

Do market prices fail to convey the true value of the earth resources? If so, how can we improve upon this situation?

These questions led me in the micl1970 s to create and develop basic needs as a central concept of economic development, and to be used as an empirical measure of economic progress in five continents in order to complement and sharpen standard measures in the areas where they fail ${ }^{\mathrm{s}-1}$ ? . Basic needs are those goods and scrvices that are necessary for humans' effective integration in their societies, for example, food, shelter, education and health. They are to a certain extent culture-dependent. I proposed that the satisfaction of basic needs of the population should be a minimum requirement for economic progress, and explored the connection between basic needs and sustainable development across the world ${ }^{0,11,2}$. Subsequently, my concept of basic needs became a standard aim of development; it is central to the concept of sustainability given in the Brundtland Report, and was adopter by 150 nations as an explicit objective in the United Nations (UN) Agenda 21, at the 1992 United Nations Conference on
Environment and Development (UNCED) in Rio de Janeiro ${ }^{8}$. Despite the international acceptance for basic needs-based development, the problem persists. The question remains: why have we reached this pattern of overproduction and overconsumption of the world's resources, beyond the point of sustainability?

\section{The past 50 years}

The onser of today's acute global environmental problems can be traced to the past 50 years. Exonomic activity has been the driving force, the leading cause of environmental degradation and biodiversity loss. The destruction of biodiversity over the past 50 years is comparable to. or at least leading to, a mass extinction event like the one that led to the disappearance of the dinosaurs ${ }^{f .8}$. The emissions of greenhouse gases followed a similar pattern: from 1860 to 1950 worldwide consumption of fossil fuels for energy consumption re leased an estimated 187 billion metric tons of $\mathrm{CO}_{2}$; however, over the past four decades, the rate of emissions was eight times higher, amounting to a total of 559 billion metric tons of $\mathrm{CO}_{2}$ (Ref. 8).

Today's unease reflects the awareness that the environmental problems we face are new, or of an order of magnitude that was not apparent before. What happened over the past 50 years, and why?

\section{The post-war world}

Fifty years ago World War II was won by the Allies. The United States of America, which led the victory, emerged with almost $40 \%$ of the world economy, following the destruction of the Japanese and European economies. Today the US is back to its prewar level, producing approximately $25 \%$ of the world's economic output ${ }^{13.14}$,

After the war, major international organizations were created: the UN, and the Bretton Woods institutions - the

\section{Box 2. Resource extraction and environmental damage}

Resources are an important scurce of exoort revenues for developing countries. However, their extraction can produce major environmental damage. An example is the salt minng project in Baja California by Exportadora de Sal, a Mitsubishi subsiciary. It mines salt destined for the international market from an area in which thousands of gray whales imigate to breed, a reserve that is the sizc of the state of New Hampshire. and regsteren with UNESCO. This oroject is opposed by the locai Gruno de los Cien in Mexico because it could produce ireversible damage to this migratory species by destroying its breediregrounds, as well as destroying the wotlands and tishenes that are crucial for the livelihood of the local communities.

Petroleum is another example - an important source of revenue for developing countries. However, oil explofation and extraction can produce major environmental damage in the producer country. For example, about $50 \%$ of the export revenues of Ecuador come from petrolsum. Exploration and extraction is largely for the iritemational market, and leads to extensive deforestation in Ecuador's Amazon forest. About $60 \%$ of the population of Ecuzdor is indigenous and ooposes oil exploration and the attendant deforestation 22 ,

Duerconsumption comes from underpricins. The price of petroleum varies widely across countries; L.S consumers pay about 2.5 times less for petroleum than do Japanese and German consumers. The use of petroleum in the US is comespondingly much higher. The US consumes about $26 \%$ of al the petroleurr produced in the worid, and emits about $25 \%$ of the world's carbon dioxide. Interestingy. almost all US imports of petroleum came from Latin America - Mexico, Venezuela and Ecuadar - even though USA is much richer in fossil fuels than these countrics are. Aboul $50^{\circ}$ of the known recoverable fossil fuel deposits in the world (oetroleum, coai, shale oil and naturai gas) are in US soil3,14,23, 


\section{Box 3. Industrialization and property regimes}

In many of the now industrialized countries, industrialization was precented by the privatizing of common property resources. During the period of industrialization, population becomes lage and mobile, and there fore private-property regimes aften work better in the conserwation of local resources than do common property regimes, which become 'open access de facto2e, For example, in the United Kingdom. industrialication was preceded by a major change in property rights - the privatization of the commons. The orivatization laws for ail ithe Hot Oil Act of 1936 in the USI provide a good example. The US extracts lit Be oil compared $w$ th the levels of extraction in developing countries with les 5 well-defined property nights on this resource, such as Mexico. This is true even though the US has enormous deposits, which Mexico does not have. The US has about $50 \%$ of all the worid's knovin recoverable fossil fuel deposits ${ }^{3,15}$, while Mexico's oil resources are expected to become exhausted early in the coming century. Although the US uses its own oil resources mare carefully, it is the largest al consumer in the word: the difference herween production and consumstion is made up by imports. The US economy is today the argest single importer of oil in the world, consuming about $26 \%$ of the world's production yearly.

International Monetary Fund (IMF), the World Bank, and the General Agreement on Trade and Tariffs (GATT). These organizations implemented the vision of economic growth of the leading nation, the USA; a very resource-intensive pattern of growth corresponding to a rapidly cxpanding frontier economy, and the domination of nature through technological change. After World War II, the Gross National Product (GNP) was adopted as a universal measure of economic progress. It is the sum of a country's net value of production of all goods and services computed at their market prices.

\section{Valuing economic progress}

Today all countries report their economic performance to the UN based on GNP. Yet some of the most fundamental resources without which humans could not survive, such as water and fertile soil, have zero weight in the GNP. There are no organized markets for water, and therefore no market prices, even though according to World Bank reports, usable water is today one of the most scarce resources in developing countries ${ }^{15}$. Similarly, there is no market and no market price for atmospheric quality or for biomass. In GNP terms, critical resources, such as the whole biomass of the planet, its water bodies and its atmospheric cover, have zero economic value.

International markets have contributed to the problem of misvaluing resources. Since the end of World War II, the world's economy has grown at a very rapid pace. However, international trade outstripped the overall growth of the world economy by a factor of three. This had important consequences, because most of the misvaluing of resources occurs through international markets. Petroleum is a case in point. In most of the world, petroleum is national property. Its extraction and exports are counted positively, by the market value of exports. However, there is no accounting for the exhaustion of the resource base, the depletion of the asset itself, Destroying a forest to export wood or pulp increases GNP and counts as eco- nomic progress. In a world concerned about the preservation of forests and their biodiversity, economics values deforestation and the destruction of biodiversity as unequivocal progress. Why?

\section{Growth and trade based on inexpensive resources}

After World War II, two major theories of economic growth and trade were developed and rapidly diffused. One was the theory of optimal economic srowth (of the type made familiar by Robert Solow) to $^{10}$ that originated in the US. It has an everexpanding view of the economy and of the economy's use of resources, which parallels the US pattern of development. It defines an optimal steady state as a path along which population growth is exponential, with a potential exponential increase in the use of resources.

The second is the theory of international trade based on comparative advantage, which originated in Sweden ${ }^{17}$. This theory was widely applied and developed in the US after World War II. It recommends that developing countries should emphasize resource exports and exports of labor intensive products, while importing technology and capital intensive goods.

These two theories advanced a vision of development based on unlimited and inexpensive resources. Even today this view is prevalent in the US; it is much less accepted in Europe and Japan. In the US, inexpensive oil is seen often as the basis for economic growth ${ }^{18}$, almost a birthright of its citizens, a right for which wars can be, and are, fought. Any attempt to redress this view meets with political failure.

These theories of growth and trade have had major implications for the way we use and trade resources in the post war period. The World Bank and the IMF provided strong incentives to developing countries to follow resource-intensive development and recommended exporting more resource intensive products as a precondition for loans and other important economic incentives. The IMF still makes the same recommendations today to Russia and Mexico.
The limitations of export-led growth based on labor or resource intensive exports have been known empirically, and have been formalized theoretically, for some time $\mathrm{e}^{[0,19-2 i}$. Yet the theory of traditional comparative advantages is largely uncontested today in Latin America and Africa - the two continents that have fallen behind in terms of economic growth in the past three decades, while following resource-intensive patterns of production and exports. Even today, a projected intensification of South American mining in the Andean region is viewed as a source of riches for the region and called the new $\mathrm{F}$. Dorado'. A doubling of Latin American resource exports to US\$25 billion by the end of the decade, mostly through the granting of generous and unobstructed exploration and extraction permits, is heralded as a triumph of markets and economic progress $^{26}$. By contrast, the theory of traditional comparative advantages has never taken hold in the successful 'four tigers' of Asia: Hong Kong, Singapore, South Korea and Taiwan. These countries never quite adopted this way of thinking2y. They hold instead a view of dynamic comparative advantages; instead of basing their growth on resources or cheap labor, they shifted swiftly into technology-intensive products. The three members of the Association of Southeast Asian Nations (ASEAN). Indonesia. Malaysia and Thailand, are also interesting examples. Malaysia took the resource-intensive route but rapidly shifted to technology-intensive development. These countries present a stark contrast to Africa and Latin America, and confirm a new vision of development and trade that is gaining ground ${ }^{19-22}$, and to which we now turn.

\section{Traditional comparative advantages}

Is it true that developing countries have a comparative advantage in environmentintensive products, such as cash crops and minerals, and in dirty industry, which uses clean air intensively? If so, does efficiency dictate that this comparative advantage should be exploited, to everyone's benefit? In sum, is there a fundamental contradiction between economic gain and environmental preservation?

The answer to these questions is no. The export patterns we observe in developing countries do not follow the law of comparative advantages, nor any other law of economic efficiency. Nor is the world better off in economic terms when the South specializes in the export of resource. intensive products, which damage the environment. The whole thing is a tragic misunderstanding of growth and trade. The correct answer to this question is simple, and it leads to a new theory of why 


\section{Box 4. Property rights and international trade}

When the oropery rights on environmental resources, such as forests, are ill-defined, at each price the country offers more resource-intensive goods. such as wood, to the intemational marketico3n. The country has an apparent comparative advantage, even when there is none. This argument explains wny countries trade with each other, based solely on the differences in property rights regimes between the trading regions ${ }^{3 .}$. Countries with il-defined property rights in resources, such as most developing countries are today, will export resource intensive products to those with better defined property rights, the industrial countries. There may be no gains from trade. Yet the exporter country is not better oft, nor is the wond better off when the developing countries specialize in resource-intensive exports. The gains are iliusory, derived from faulty valuations of resources.

Lnder these circumstances, export-led policies based on resource-intensive products iead to apparen gans from trade, even when trade leads to antual iasses. Anomalies emenge: Honduras exports mahugamy to the US even though it has no comparative aovantage in wood products; Mexico exports petroleum to the US even though it has small resenves. The US, a major oil importer since the 1970 s, has $50 \%$ of the reco\% erable fossil fuel resurces on the planet's. countries trade resources, and how these resources are valued ${ }^{19,20,30}$. It hinges on differences in property rights in the trading regions.

\section{Property rights and industrialization}

Many traditional societies have successfully managed their common property resources, such as fisheries and forests, using traditional forms of governance ${ }^{31-34}$. The term 'common property' relers to ownership that is shared by a group, rather Valencia's 'Tribunal de las Aguas', a local Court in Spain that is 1000 years old, and which still meets on a weekly basis to administer costs and allocate the use of the regions' water network. (Other examples include the Iriaichi system of managing common lands in Japan, and Bahia's system of sea tenure in the North East of Brazil $^{2030-34}$. These traditional systems require a small and stable population, where penalties from antisocial overuse of resources can be administered effectively and, if necessary, across generations.

Such systems of resource management tend to break down in the period of industrialization in which outsiders move into the common property area, outsiders who can easily move out and avoid penalties. During the process of industrialization populations become large and mobile and can easily escape penalties from overuse. Well-managed common property is transformed into unmanaged 'open access' resources, which can be had for the taking. A 'first come first served' system prevails $21,31-34$ (see Box 3).

\section{Property rights explain prices and trade}

When a pool from which a resource is extracted, such as a forest, is treated as open access, the only cost computed is the cost involved in the actual extraction. Often this is just the time and energy it takes to cut and remove the trees. The cost of replacing the tree to ensure the continuation of the forest is not considered. than individual ownership. An example is
The loss of the services that the forest provides to human settlements, such as providing an ecosystem for biodiversity, shelter, stable climate and food are not computed. Similarly, in the extraction of a national asset such as petroleum, the only costs computed are those of exploration and extraction: the exhaustion of the re source base itsclf, that is, its depreciation, is not counted as it is in the case of private property. Nor are the costs from deforestation during the process of exploration for petroleum, for example in Ecuador's Amazonas $20,30,34$. Because costs are undervalued, the net benefits from extraction are overestimated. At each market price, more is extracted under open access regimes than under private property regimes or under traditional managed systems ${ }^{20}$. Hence, the resource is overextracted, it dwindles and often disappears $20,3 n, 34$

The country with open property resources offers more of the resource to the international market than is efficient. At each market price the quantity offered is greater with open access than it is with private property ${ }^{20}$. This leads to an apparent comparative advantage in the production of environmentally intensive products, even when there is no real comparative advantage (see Box 4).

This explains why developing countries, which have on the whole ill-defined property rights for envirommental resources, export resource-intensive prod- ucts even if they have no comparative advantage in such products ${ }^{20}$. It explains why resource-intensive products such as refined oil, wood and food are exported at such low prices, below real costs. Resources are overconsumed by the countries with well-defined property rights and overproduced by those with ill-defined property rights. As a result, the world economy consumes an inefficiently large quantity of resources, because it takes no account of the costs of the resource overuse. In brief, the process of industrialization itself leads to the inefficient patterns of North-South trade, that are at the core of the environmental dilemma today, It leads to international prices for resources that are well below the actual costs to society.

\section{The economic value of the Earth's resources}

\section{Green accounting}

One proposal to correct this problem is to modify the way we account for resources. The idea is to report the costs of using the euvironment within the national accounts. This is generally called 'green accounting (see Box 5). The procedure requires, however, that environmental assets be priced correctly. How is this to be achieved?

\section{Environmental markets and prices}

Where will prices for forests, water, biodiversity and clean air come from? Economists say from free markets. There is a lot of merit as well as optimism in this premise: under ideal conditions, market prices lead to efficient outcomes that represent the preferences of the population. Water markets are considered currently in California, the Chicago Board of Trade already trades rights to emit $\mathrm{SO}_{2}$, and 1 recently proposed global markets for global $\mathrm{CO}_{2}$ emissions.

But we can't trade unless we know who owns what: we need property rights on forests, water, air and biodiversity. Can we carefully parcel out the Universe and assign property rights on each piece? This seems a tall order, perhaps too tall for the

\section{Box 5. Green accounting}

A proposal that is currently under consideration by the UN is ta modify the system of national accounts to incorporate environmental costs. Green accounting is the practice of deducting erivironmental costs from the computation of the GNP. For example, the natonal acoaunts would depreciate the value of the stock of forests or of minerals cxtracted, in much the same way that private ind viduals and corporations dopecciate the value of their own stork or assets when reporting their personal or corporate incume.

Green accounting can indeed help in reducing the overuse of resources, and their excess ive extraction by reporting the costs from extractions more accurately. Under green accounting the export. reveriues are. added, but the decrease or deoreciation of the asset exported is subtracted from the equation. This can help correct the problem of lack of property rights on resources, which induces a misleading view of comr paralive advantages and gains from trade by overestimating the net value of extraction and exports. Green accounting can make a large difference in reporting economic pertormance in resource intensive countries. The GNP of Costa Rica and Mexico were recently recomputed using this practice, and they both dropped to a fraction of their former level as computco from standard practices. 
urgency with which some feel the environmental prohlem must be tackled.

\section{Efficiency and equity in environmental markets}

Even if the universe was parcelled out successfully, a problem remains: how to distribute property rights? How to assign its pieces across people, regions or even across generations? This is a problem of equity. It is generally of no importance for the economic efficiency of competitive markets with private goods, as they are usually defined, although of course it matters on ethical grounds.

However, the neat separation of efficiency and equity may not work in markets in which environmental assets are traded. It is important to understand why. Often it is not possible for different individuals to choose different quantities of environmental assets independently from each other, as required for efficient markets. For example, the concentration of $\mathrm{CO}_{3}$ in the atmosphere of the planet is relatively uniform and stable, and everyone in the planet is exposed on the whole to the same concentration. The total biodiversity in the planet, regardless of the way it is measured, is the same for us all. These constraints are physical, not economic or legal. For this reason, biodiversity and $\mathrm{CO}_{2}$ concentrations are often called 'public goods', and their sources are 'global commons'. These are, however, unusual public goods in that they are produced privately.

A new finding is that only particular 'equitable' distributions of a given total of property rights can lead to efficient markets in those markets with privately produced public goods ${ }^{2-4}$. It was recently established that only with such distributions of property rights one can ensure that market prices will lead to efficient allocation of resources (see Box 6).

\section{Knowledge-intensive growth}

Property rights must be sorted out properly for environmental markets to achieve efficiency ${ }^{4}$. This requires careful market design, and will not be achieved immediately. In emergencies, taxes or bans on the trading of species that are close to extinction may be necessary: examples include trade in elephant tusks, in tiger parts, in US box turtles, commercial hunting, and more recently tlie meat trade in the UK ${ }^{1}$. Trade in human parts has related aspects. Humans' irrational cruelty to animals - and to each other-admits on occasion no other redress.

Is it possible to reorient patterns of trade and development without interfering with free trade? To a certain extent this is possible $20-22$. The trade strategies followed by the Asian Tigers - Japan, Korea, Taiwan, Hong Kong and Singapore - and more

\section{Box 6. Private goods and public goods}

Private goods are goods whose consumption is 'rival', in the sense that what one person consumes others cannot. The levels of consumption can be chosen independently by each person. Examples of private goods are eatable products. Public goods differ from orivate goods in that they are available to everyone in about the same amount, and, within limits, are no: 'rival' in consumption; for example, a road, a bridge or clean air. Furthermore. with public goods one person's consumption need not detract from others'. A good example is knowledge: one may share knowledge with others without losing it aneself. Of course, kncwledge shou d not be identfied with the financial gains that can be obtained from it.

Classic public goods such as roads and bridges are supplied by govemments. Biodiversity or greenhouse gas concentrations in the atrnosphere are public goods, but they are not classic public goods because they are not aroduced by govemments as roads or briges are. They are produced, rather, by each individual in the economy, Carbon emissions are 'produced' privately, by people driving their cars or by producers buming fossil fuels to release energy. These are private activities that a government does not generally regulate.

The trading of private goods is very different from the trading of public goods. In markets with private goods, efficiency is divorced from equity in the sense that under any distribution of property rights, a competitive market with private gocds achieves an efficient outcome at a market equilibrium. This is not true in markets with public goods. It has been shown recently that in such markets there is a relation between efficiency and equity 4 . A rigorous general equ librium treatment of markets in which some of the goods are private, and others are privately produced public goods. such as property rights on emission of carbon dioxide, shows that certain property rights regimes on the use of global enwironmental goods are consistert with the effic ent operation of competitive markets. and others are not. A certain 'equity' is needed for environmental markets to operate efficiently 24 recently the Little Tigers, such as Malaysia, provide good examples. These are very export-oriented countries that moved away swiftly from traditional comparative. advantages, such as labor-intensive and resource-intensive products, into knowledge-intensive products, such as microprocessors, consumer electronics, communications, financial products, and many other technology-based products. These knowledge-intensive sectors are the most dynamic sectors in the world economy today.

A possible development strategy is to emphasize knowledge-intensive rather than resource-intensive sectors. This economic strategy was introduced formally a few years ago ${ }^{15-22}$, and received further impetus from the empirical evidence of world development, some of which is discussed here.

The knowledge-intensive sectors listed above require human capital and knowhow rather than large plants and equipment. Furthermore, these sectors are often competitive, and therefore efficient: the computer hardware industry is a good example.

The skilled labor required for knowledge-intensive sectors is available in many developing countries ${ }^{35}$ (Box 7). It is well known that Mexico is currently a producer of electronic products such as microchips and software, and that lndia could become one of the largest exporters of software in the world. Software is very labor-intensive and suits the Indian and Mexican economies as it does not require large capital outlays. More recently Barbados' government announced its determination to transform the country into an information age society in less than a generation, based on its excellent educational system ${ }^{36}$.

\section{Conclusions: information and resources}

Knowledge-intensive growth is successful in economic terms. It drives the most dynamic sectors in the world today. For the purposes of this article, however,

\section{Box 7. Education and technology}

Many authors are concerned that educational conditions in developing countries may not allow the transt lion from resource-intensive production to knowledpe-based production in the near future. This was not a problem in the case of the East Asian countries. which developed rapidly. Recent empirical work at the Interamencan Development Bank in Washington belies this view for the Caribbean region as well ${ }^{25}$. The initial conditions found in Caribbean countries 20 years ago, in tems of education and generally the satis faction of basic needs, matched those of the East Asian economies at the same period ${ }^{35}$. However in the past 20 years the East Asian countries moved rapidly towards technology-intensive oractices and succeeded. The Carlabean countries, and indeed the whole of Ceritral and South America, emphasized instead resource-intensive growth and lost ground. Even today, Latin America emphasizes resource exports. Mineral exports from the region are expected to double to achieve a level of US\$25 billion by the end of the decade. An unfortunate and dated view of growth and trade perceives this increase in resource inten sity as a 'the new El Dorado' for the region 23 .

The trend is not uniform. Today, Barbados is redressing this policy and attempting to make a swift tran sition towards an information-age society. Mexico and India already have active computer hardware and soitware sectors. Those nations that emphasize knowledge intensive growth will move forwards and inte grate with the most dynamic regions in the world economy; the rest will decay and languish at the cost of much human and environmental loss. 
its most important aspect is that knowledge-intensive growth does not require intensive use of the environment. It is intrinsically compatible with the global environment.

Information and resources appear to be the most important trends in the world economy today, and if properly understood and harnessed, could lead to economic prosperity that is harmonious with the global environment.

How will all this affect the economic value of the Earth's resources? As we change our emphasis away from resource production and exports, the world's available supply of resources will decrease. Therefore resource prices will increase. This means that resources will be better valued, and this is as it should be. By undervaluing the Earth's resources we undervalue ourselves.

\section{References}

1 Anon. (1994) The price of imagining Arden: how do you put a value on the environment? The Economist 3 -9 Decemher, 80

2 Chichilnisky, (i. (1994) The abatement of carbon emissions in industrial and developing countries, in $O E C D$ : The Economics of Climate Change (Jones, T., ed.) pp. 159-169, Organization for Economic Cooperation and Development, Paris

3 Chichilnisky, G. and Heal, G.M. (1994) Who should abate carbon emissions?: an International perspective, Econ. Lett. 44, 443-449

4 Chichilnisky, G., Heal, G. and Starrett, D. (1993) Equity and efficiency in international markets with emission permits, Center for Econamic Poticy Research Publicution No 81, Stanford University

5 Chichilnisky, G. (1994) What is sustainahle development? Technical Report ivo 65 Stauford Institute for Theoretical Economics

6 Kalin, M.T., Raver, P.H. and Sarukhan, J. (1992) Blodiversity, in An Agenda of Science for Environment and Denelopment in the 2Ist Century (Dndge, I., Goodman, G. and Ja Riviere, J., eds), Cambridge University Press

7 Chichilnisky, G, and Heal, G, M. (1993) Global environmental risks, J. Econ. Persp. 4, 65-86

8 WRI, UNEP, LNDP (1995) World Resources: People and the Environment (1994-95) A Guide to the Global Envoroment, Oxford Lniversity Press

9 Chichilnisky, G. (197i) Economic development and efficiency criteria in the satisfaction of basic needs, Appl. Wath. Model. 1. $290-297$

10 Chichilnisky, G. (1977) Development patterns and the international order, $J$. Int. Affuirs 1 . 275-3044

11 Chichilnisky. G. (1982) Basic needs and resources in the North-Sonth debate, Worid Onders Models Project, Working Paper No. 21, Institute for World Order

12 Herrera, A.H. el al. (1976) Calastraphe or New Saciety, A Latin American World Model, International Development Research Center. Ottawd, Canada

13 Maddison, A. (1982) Phoses of Capitalistic Denelopment, Oxford University Press
14 World Bank (1994) Wonld Tables 1994: A World Bank Book, The John Hopkins University Press

15 World Development Report (1992) Deuelopment and the Ensimment, Oxford University Press

16 Solow, R.M. (1956) A contribution to the theory of economic growth, Q. J. Econ. 65. $65-94$

17 Heckscher, E. (1919) The effect of foreign trade on the distribution of income, Ekon Tidskr. 21, 1-32

18 Nordhaus, W. (1993) The allocation of energy resources, in The Economics of Exhaustible Resources (Heal, G.M., ed.), pp. 245-292, E. Elgar Publishing

19 Chichilnisky, G. (1981) Terms of trade and domestic distribution: export led growth with abundant labor, J, Dev. Econ. 8, 163-192

20 Chichilnisky, G, (1994) North-South trade and the global environment, Am. Econ. Rev. 84 , $851-871$

21 Chichilnisky, G. (1995) Strategies for trade liberalization in the Americas, in Trade. Liberulization in the Americas, pp. 165-188. Interamerican Development Bank (IDB) and United Nations Fxonomic Commission for Latin America and the Caribbean (ECLAC)

22 Chichilnisky. G. Trade regimes and GATT: resource intensive growth $v s$ knowledge intensive growth, I. Int. Comp. Econ. (in press)

23 Heal, G. and Chichilnisky, G. (1991) Oit and the Intemational Economy, Oxford University Press

24 Runge. C.F. (1994) The Grains Sector und the Envimnment. Basic Issues and Imptications for Tradc, Report to the Food and Agriculture Organization (FAO) Rome, Center for International Food and Agricultural Policy, Department of Applied Economics, University of Minnesota
25 Barbier, E.B., Bockstael, N. and Strand, L. (1993) The timber trade and tropical deforestation in Indonesia, LEEC Discussion paper 93-01. London Environmental Fxonomics Centre

26 Burgess, JC. (1993) Timber production, timber trade and tropical deforestation, AMB/O 22, 136-143

27 Barbier, E.B. et ol. (1994) The Economics of the Tropical Timber Trade, Earthscan

28 Anon. (1995) South American mining: El new El Dorado, The Economist, 2-8 September, 59-60

29 Lindauer, D.L and Roemer. M. (1994) Development in Asia and Africa: Legacies and Opportumities, ICEG and Harvard Institute for International Development

30 Chichilnisky, G. (1993) North-Sonth trade and the dynamics of renewable resources, Struct. Change Econ. Dyn. 4, 219-248

31 Runge, C.F, and White, T.A. (1994) Common property and collective action: lessons from cooperative watershed management in Haiti, Econ Dev. Cuit. Change 1-41

32 Bromley, D.W. (1991) Envimontment and Economy. Property Rights and Public Policy. Blackwell

33 Ostrom, E. (1990) Goveming the Commons the Ecolution of Institutions for Collective Action, Cambridge Lniversity Press

34 Dassupta, P. and Heal, G.M. (1.979) Fcomomic Theory and Exhaustible Resources, Cambridge University Press

35 Harris, D. (1994) Defenniniants of Aggreggote Export Performance of Caribbeon Countries: A Compurative Analysis of Burtudes. Cosia Rica. Dominican Republic, Jamaica, Trinidad and Tobago, Interamerican Development Bank, Wishington D.C., and Department of Economics, Stanford University

36 Fidler, 5. (1995) An Information age society is booming. Financial Times, 26 April

Current trends
- articles of ecological or evolutionary interest
in recent issues of other Trends magazines
- Modulators of immune responses: the evolutionary trail, C.J. Bayne
and I.T. Zelikoff, Immunology Today $17,55-57$
- Plant-parasite interactions: has the gene-for-gene model become
outdated? R.W. Innes, Trends in Microbiology $3,483-485$
- RNA editing, introns and evolution, $A$. Herbert, Trends in Genetics
12, 6-8
- Trade-offs in parasitology, evolution and behavior, $M$. Zuk et al.,
Parasitology Today $12,46-47$
- Evolutionary biology of parasitic platyhelminths: the role of
molecular phylogenetics, D. Blair et al., Parasitology Today $12,66-71$
an m

